\title{
MANAJEMEN KAMPANYE ELIMINASI KAKI GAJAH DALAM UPAYA PENINGKATAN KESEHATAN DI KABUPATEN BOGOR
}

\author{
Seftia Rahmaning Tyas ${ }^{1}$, Hanny Hafiar ${ }^{2}$, dan Anwar Sani ${ }^{3}$ \\ ${ }^{1}$ Komisi Pemilihan Umum Kabupaten Bogor \\ ${ }^{2,3}$ Universitas Padjadjaran
}

\begin{abstract}
ABSTRAK
Penelitian ini bertujuan untuk mengetahui proses prakampanye, proses pengelolaan kampanye, dan hasil evaluasi kampanye oleh Kementerian Kesehatan. Penelitian ini menggunakan konsep manajemen kampanye oleh Antar Venus yang dikembangkan berdasarkan Model Kampanye Ostergaard. Penelitian ini menggunakan metode deskriptif dengan data kualitatif. Teknik pengumpulan data dilakukan dengan wawancara, teknik dokumen, studi kepustakaan, dan angket menggunakan teknik pengumpulan informan dengan purposive sampling. Teknik analisis data menggunakan deskriptif kualitatif, sedangkan teknik validitas data menggunakan triangulasi sumber. Hasil penelitian ini mengemukakan bahwa proses kampanye Belkaga dibagi dalam tiga tahap yaitu prakampanye, pengelolaan kampanye, dan evaluasi kampanye. Hasil prakampanye menyatakan bahwa masih banyak daerah di Indonesia yang merupakan daerah endemis dan belum melaksanakan program Pemberian Obat Pencegahan Massal Filariasis (POPMF). Hasil pengelolaan menunjukkan bahwa Kementerian Kesehatan RI tidak melakukan identifikasi segmentasi sasaran berdasarkan klasifikasi warga yang sehat, terduga tertular virus, serta warga yang teridentifikasi penyakit sehingga pesan yang disampaikan dibuat sama rata. Selain itu, penyebaran informasi yang kurang jelas mengakibatkan pesan yang diterima khalayak tidak sesuai dengan apa yang ingin disampaikan komunikator. Kesimpulannya, masalah kampanye Belkaga timbul karena manajemen kampanye yang kurang efektif oleh Kementerian Kesehatan RI. Peneliti menyarankan agar Kementerian Kesehatan RI menyesuaikan pesan berdasarkan klasifikasi warga sehat, terduga tertular virus, serta warga yang teridentifikasi penyakit sehingga pesan tepat sasaran, mengoptimalkan media yang digunakan, memberikan pelatihan penyampaian informasi kepada kader kesehatan.
\end{abstract}

Kata-kata Kunci: Manajemen, kampanye, manajemen kampanye, belkaga, bulan eliminasi kaki gajah, kementerian kesehatan RI

\section{CAMPAIGN MANAGEMENT OF ELEPHANTIASIS ELIMINATION AS EFFORT OF HEALTH IMPROVEMENT IN BOGOR REGENCY}

\begin{abstract}
The purpose of this research is to identify the pre-campaign process, campaign management process, and the result of campaign evaluation by the Ministry of Health. This research took the management concept by Antar Venus which developed based on the Ostergaard Campaign Model and is using descriptive method with qualitative data. The data was collected by interviews, technical documents, literature studies, and questionnaires through informants with purposive sampling. The data was analyzed by using descriptive qualitative, while the data validity technique was using the triangulate source.The results of this research propose that Belkaga campaign process which divided into three stages which; pre-campaign, management campaign, and campaign evaluation. The pre-campaign has resulted that there are many region in Indonesia which is the endemic area and have not using the Filariasis Preventive Mass drug Admnistration (MDA) program. The management's result has shown that Indonesia's Ministry of Health do not identify target segmentation based on classification of those who are healthy, allegedly contaminated, and sick get the same messages from the campaign. Meanwhile, uneven dissemination of information has causes the received message by the audiences is not in accordance to what the communicator has to deliver. It concludes that the campaign's problem are caused by ineffective campaign management from Indonesia's Ministry of Health. The researcher suggest that Indonesia's Ministry of Health should identify the campaign target based on classification before to get the right message, optimize the media, and give a proper training in sharing information to the volunteers.
\end{abstract}

Keywords: Management, campaign, campaign management, belkaga, elimination month of elephanthiasis, indonesia's ministry of health

Korespondensi: Seftia Rahmining Tyas, S.I.Kom. KPU Kab. Bogor, Jln. Moh Noh Nur, No. 05 Kecamatan Leuwiliang, Kabupaten Bogor, Jawa Barat 16640.Email: tyaseftia12@gmail.com 


\section{PENDAHULUAN}

Filariasis (penyakit kaki gajah) adalah penyakit menular yang mengenai saluran dan kelenjar limfe disebabkan oleh cacing filarial dan ditularkan oleh nyamuk. Penyakit ini bersifat menahun (kronis) dan bila tidak mendapatkan pengobatan dapat menimbulkan cacat menetap, berupa pembesaran kaki, lengan dan alat kelamin baik pada perempuan maupun laki-laki. Akibatnya, penderita tidak dapat bekerja secara optimal bahkan hidupnya bergantung kepada orang lain sehingga menjadi beban keluarga, masyarakat dan negara (Infodatin, 2014).

Penderita Kaki Gajah dapat mengalami stigma tersingkir dari lingkungannya dan menghadapi kesulitan sosial dan ekonomi yang berat bagi dirinya dan keluarganya. Filariasis selain menyebabkan dampak sosial dan psikologik, juga ditetapkan oleh WHO sebagai penyebab kecacatan permanen nomor dua. Program pemberantasan filariasis sendiri sebenarnya telah dilaksanakan sejak 40 tahun lalu, yakni pada tahun 1975, terutama di daerahdaerah endemis yang tinggi (Infodatin, 2014).

Pada tanggal 8 April 2002 Menteri Kesehatan Republik Indonesia telah mencanangkan dimulainya eliminasi penyakit Kaki Gajah di Indonesia dan telah menetapkan eliminasi Kaki Gajah sebagai salah satu program prioritas. Sebagai pedoman, Pengendalian Filariasis (Penyakit Kaki Gajah) tertuang dalam Keputusan Menteri Kesehatan Republik Indonesia Nomor: 1582/MENKES/ SK/XI/2005 Tanggal 18 November 2005. Sampai tahun 2014 berdasarkan survei darah jari, dari 511 kabupaten/kota di Indonesia ada 241 kabupaten/kota sebagai daerah endemis, dari 241 kabupaten/kota tersebut, sebanyak 46 kabupaten/kota telah melaksanakan POPM Filariasis minimal 5 tahun berturut-turut dengan cakupan pengobatan di atas $65 \%$ berhasil menurunkan microfilaria pada masyarakat menjadi $<1 \%$.

Sementara itu 195 kabupaten/kota lainnya akan melaksanakan POPM Filariasis tahun 2015-2019. POPM Filariasis adalah sebuah program untuk melakukan pencegahan penyakit Filariasis secara massal atau merupakan kepanjangan dari Pemberian Obat Pencegahan Massal. Program ini harus dilaksanakan tiap daerah yang dinyatakan endemis Filariasis dan merupakan bagian dari program kampanye Belkaga. Maka, untuk mempercepat terwujudnya Indonesia Bebas Kaki Gajah, diselenggarakanlah kampanye Bulan Eliminasi Kaki Gajah (Belkaga) setiap bulan Oktober selama lima tahun berturut-turut dimulai sejak 2015 lalu (Infodatin, 2014).

Menurut data WHO, saat ini 39 negara sudah berada di jalur yang tepat untuk mencapai eliminasi kaki gajah pada tahun 2020. WHO terus bekerja sama erat dengan Pemerintah Indonesia melalui penyediaan dukungan teknis, pengobatan massal, advokasi, dan komunikasi publik. Setelah dicanangkannya Belkaga ini, setiap bulan Oktober, sejumlah penduduk di 241 kabupaten/kota endemis penyakit kaki gajah, harus melaksanakan Pemberian Obat Pencegahan Massal (POPM) (BPOM RI, 2015).

Berdasarkan wawancara yang telah dilakukan dengan dr. Intan Widayati dari Dinas Kesehatan Bogor, program ini pernah diselenggarakan di tahun-tahun sebelumnya, tetapi hanya di daerah yang endemisitasnya tinggi saja. Sementara itu mulai tahun 2015, kampanye tersebut diselenggarakan lagi dalam skala besar yakni secara nasional karena telah ditemukan hasil penelitian yang menyatakan bahwa masih ada daerah-daerah di Indonesia yang endemis filariasis, khususnya di Kabupaten Bogor yang belum melaksanakan Pemberian Obat Pencegahan Massal Filariasis atau POPMF, maka harus mengikuti program WHO untuk eliminasi Filariasis.

Data statistik divisi Dermatologi umum Departemen Ilmu Kesehatan Kulit dan Kelamin FKUI/RSCM menyatakan bahwa, berdasarkan survei jari tahun 1999, tingkat endemisitas filariasis di Indonesia masih tinggi dengan microfilarial rate $3,1 \%$. Daerah endemis filariasis adalah daerah dengan microfilarial rate $\geq 1 \%$. Disebutkan dalam Petunjuk Teknis dan Petunjuk Pelaksanaan Filariasis (Juknis Juklak Filariasis) 2015 Pemkab Bogor, hingga tahun 2015 lalu di Kabupaten Bogor telah ditemukan 60 kasus penyakit kaki gajah (filariasis) yang tersebar di 22 Kecamatan. Kasus elephantiasis 
berasal dari wilayah Kecamatan Rumpin, Gunung Sindur, Sukamakmur, Cisarua, Tenjo, Ciomas, Parungpanjang, Sentul, Bojonggede, Tenjolaya, Dramaga, Cariu, Citeureup, Parung, Jasinga, Cijeruk, Cibungbulang, Ciawi, Karadenan, Jonggol, Tajurhalang dan Cibinong. Hasil pemeriksaan cross check sampel Filariasis di Kabupaten Bogor menunjukkan Mikrofilaria Rate 1,92\% sehingga ditetapkan Kabupaten Bogor sebagai daerah endemis Filariasis, yang selanjutnya menjadi dasar pelaksanaan Pengobatan Masal Filariasis selama lima tahun berturut turut dari tahun $2015 \mathrm{~s} / \mathrm{d} 2019$.

Menurut petunjuk teknis dan petunjuk pelaksanaan kampanye Belkaga, kegiatan yang dicanangkanolehMenkestersebutbertujuanagar terselenggaranya kegiatan Sosialisasi Penyakit dan Pemberian Obat Massal (POPM) Filariasis di seluruh Kecamatan wilayah Kabupaten Bogor guna mencegah dan memberantas penyakit gajah/filariasis. Sementara itu tujuan khusus lainnya dalam rangka mewujudkan tujuan yang telah disebut sebelumnya adalah dengan meningkatkan kemampuan petugas puskesmas dalam pelaksanaan eliminasi filariasis, meningkatkan kesiapan masyarakat dalam pelaksanaan kegiatan pengobatan masal, membuat acuan untuk keseragaman pelaksanaan eliminasi filariasis di puskesmas, serta memenuhi Target Cakupan minimal 75\% dari seluruh penduduk Kabupaten Bogor.

Sayangnya, masih terdapat hal-hal yang belum sepenuhnya terlaksana dengan baik, sehingga tak sedikit halangan serta rintangan di tengah keberlangsungan pelaksanaan dari kampanye itu sendiri. Salah satunya adalah kurangnya sosialisasi dari otoritas kesehatan setempat yang kemudian menjadi alasan timbulnya kesalahpahaman masyarakat yang takut akan isu-isu yang sudah tersebar mengenai reaksi atau efek samping dari meminum obat pencegahan penyakit Kaki Gajah.

Hal ini terlihat dari jumlah total cakupan yang kurang memenuhi target minimal di beberapa daerah di Kabupaten Bogor. Seharusnya, minimal mencapai $75 \%$ hingga $85 \%$, tetapi Kabupaten Bogor hanya dapat merealisasikan total cakupan sebesar $67 \%$ saja, berdasarkan wawancara yang dilakukan dengan pihak Dinkes.

Berdasarkan pemaparan tersebut, peneliti melihat bahwa masalah dalam penelitian ini timbul karena pesan yang disampaikan oleh komunikator tidak sesuai dengan apa yang diterima oleh komunikan. Sehingga, masih ada warga yang tidak mematuhi pesan kampanye. Adanya perbedaan pemahaman pesan antara komunikator dengan komunikan merupakan masalah dalam pelaksanaan kampanye. Selain itu, pembentukan pesan merupakan salah satu unsur penting yang terdapat di dalam manajemen kampanye. Hasil yang tidak sesuai dengan target pencapaian juga memperlihatkan bahwa adanya pengelolaan kampanye yang kurang efektif sehingga perlu dicari tahu hal apakah yang telah dilewatkan oleh pelaksana kampanye.

Peneliti menemukan hal tersebut menjadi daya tarik bagi penelitian ini, sehingga peneliti berusaha untuk mendeskripsikan Manajemen Kampanye Bulan Eliminasi Kaki Gajah melalui individu-individu yang terlibat dalam kegiatan tersebut. Penelitian ini menggunakan metode deskriptif sebagai tujuan utamanya untuk menggambarkan secara sistematis fakta dan karakteristik objek dan subjek yang diteliti secara tepat. Kampanye Nasional Bulan Eliminasi Kaki Gajah yang dilakukan oleh Kementerian Kesehatan RI memiliki ketidaksesuaian terhadap konsep tahapan manajemen kampanye yang dikemukakan oleh Venus.

Menurut Venus, manajemen kampanye terdiri atas tiga tahapan, yaitu pada tahap pra kampanye, pengelolaan, dan evaluasi. Pada penelitian ini, peneliti ingin meneliti dan menggali lebih dalam mengenai permasalahan dalam manajemen kampanye Bulan Eliminasi Kaki Gajah yang dilakukan oleh Kementerian Kesehatan RI dalam upaya pengingkatan kesehatan di Kabupaten Bogor.

Johnson-Cartee and Copeland (1997: 21) menyebut kampanye sebagai an organized behavior, harus direncanakan dan diterapkan secara sistematis dan berhati-hati. Hal ini menunjukkan bahwa kegiatan kampanye membutuhkan sentuhan manajemen yakni merancang, melaksanakan, mengendalikan, dan mengevaluasi suatu program kegiatan secara 


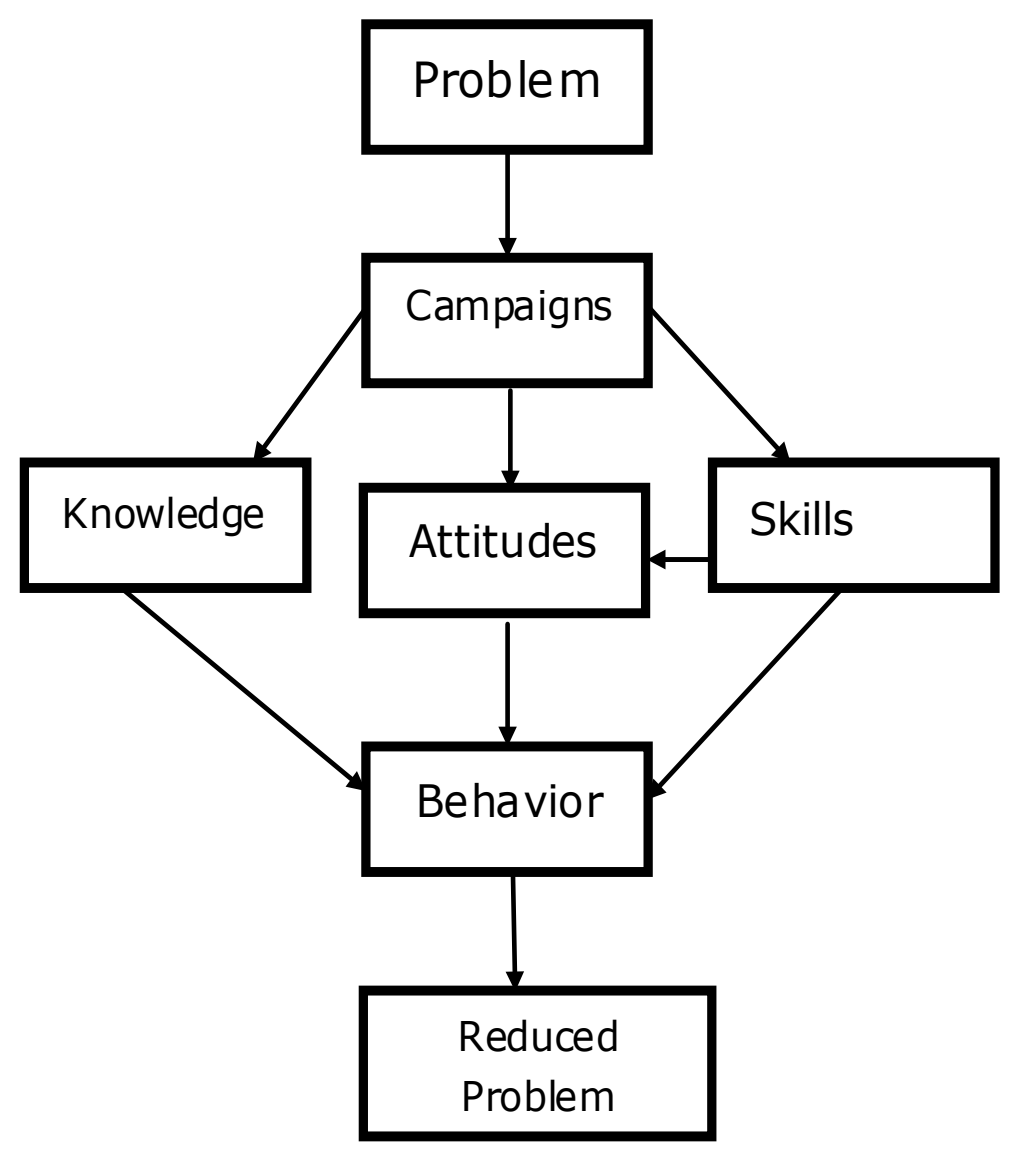

Sumber: Johnson-Cartee and Copeland (1997: 21)

\section{Gambar 1 Model Kampanye Ostergaard}

rasional, realistis, efisien, dan efektif (Venus, 2009: 26). Sejak awal, kegiatan kampanye selalu meliputi tahapan perencanaan, pelaksanaan hingga evaluasi. Perbedaannya adalah pada masa kini berbagai tahapan tersebut dibakukan dan diformalkan dengan istilah manajemen kampanye secara efektif dan efisien dengan memanfaatkan seluruh sumber daya yang ada guna mencapai tujuan yang telah ditetapkan. Dimasukannya unsur manajerial dalam pengelolaan kampanye diharapkan peluang keberhasilan pencapaian tujuan kampanye menjadi lebih terbuka dan lebih besar. (Venus, 2009: 26)

Model manajemen kampanye dan model kampanye Ostergaard yang menjadi landasan dalam penelitian ini penulis sajikan dalam Gambar 1. Di antara berbagai model kampanye yang ada, modelOstergaard menghasilkan model yang paling pekat sentuhan ilmiahnya. Oleh karena itu, Venus memilih model Ostergaard ini sebagai model terbaik untuk digunakan dalam membuat kampanye yang bertujuan untuk perubahan sosial. Dikembangkannya model Ostergaard ini menjadi buah pikirnya sendiri yang dituangkan dalam buku manajemen kampanye. Venus mengembangkan model Ostergaard ini dengan membuat istilah dan tahapan kampanye yang berbeda dari apa yang dikemukakan dalam model Ostergaard. Tahapan kampanye yang dinyatakan oleh Venus tersebut dibagi menjadi tiga tahap yaitu prakampanye, pengelolaan kampanye, dan evaluasi.

Tahap pertama yaitu pra kampanye atau identifikasi masalah, dalam tahap ini pembuat keputusan atau pelaksana kampanye melihat fakta-fakta yang terjadi dalam lingkungannya sebagai masalah. Menurut Ostergaard sebuah rancangan program kampaye untuk perubahan sosial yang tidak didukung oleh temuan-temuan ilmiah tidaklah layak untuk dilaksanakan. Maka dari itu, sebuah program kampanye hendaknya selalu dimulai dari identifikasi masalah secara jernih (Venus, 2009: 15). Pada tahap identifkasi masalah tersebut akan dicari hubungan sebabakibat (cause and effect relationship) dengan 
fakta-fakta yang ada. Apabila dari analisis ini diyakini bahwa masalah tersebut dapat dikurangi melalui pelaksanaan kampanye maka kegiatan kampanye perlu dilaksanakan (Venus, 2009: 16).

Tahap prakampanye ini penting untuk memaksimalkan kemungkinan meraih keberhasilan dalam kampanye, sebab hal itu dapat memberikan gambaran nyata mengenai sejumlah besar kampanye-kampanye yang dilakukan tetapi kampanye tersebut tidak dilandasi dengan penelitian yang rasional untuk mencapai keberhasilan dan biasanya hasil kampanye tersebut dapat dipastikan tidak akan memuaskan. Persoalannya adalah kampanye-kampanye yang biasanya dilakukan tanpa didasari penelitian maupun dasar-dasar teori akan memerlukan pembiayaan luar biasa besarnya, sehingga berdampak pada kehidupan bisnis dan berimplikasi pada kehidupan sosial kemasyarakatan, kondisi seperti ini dapat berlangsung selama berminggu-minggu, berbulan-bulan dan bahkan bisa mencapai tahunan, untuk itu banyak sekali persoalan yang harus ditangani sebelum kampanye berlangsung.

Venus (2009: 147) menyatakan bahwa dalam melakukan analisis masalah hendaknya dilakukan secara cermat dan terstruktur, agar masalah tersebut dapat diidentifikasikan dengan jelas. Selain itu, pengumpulan informasi yang berhubungan dengan permasalahan harus dilakukan secara objektif dan tertulis agar terhindar dari pemecahan masalah yang tidak tepat. Penelitian ini dapat dilakukan oleh pihak eksternal maupun internal. Penelitian dapat bersifat kuantitatif yang menggunakan data berbentuk angka dan statistik, dan penelitian bersifat kualitatif yang membutuhkan data yang tidak bisa dibentuk dengan angka, seperti opini, reaksi, dan sikap. Penelitian itu dapat dilakukan dengan teknik seperti menyebarkan angket, wawancara langsung atau tidak langsung, focus group discussion, atau melalui informasi yang terdapat di media.

Berdasarkan analisis identifikasi masalah tersebut, selanjutnya wajib dilakukan penyusunan tujuan kampanye yang harus disusun dan dituangkan dalam bentuk tertulis, dan bersifat realistis. Penyusunan tujuan yang realistis ini bertujuan agar kampanye yang akan dilaksanakan mempunyai arah yang terfokus pada pencapaian tujuan tersebut. (Venus, 2009: 147). Tujuan dari kampanye sangat beragam dan berbeda antara satu organisasi dengan organisasi yang lainnya. Ostergaard (2002) dalam Venus mengatakan ketiga aspek tersebut dengan sebutan "3A" yaitu, awareness, attitude, dan actions. Ketiga aspek ini bersifat saling berkaitan dan merupakan sasaran pengaruh (target of influences) yang harus dicapai secara bertahap agar satu kondisi perubahan dapat tercipta.

Tahap kedua yaitu pengelolaan kampanye yang dimulai dari perancangan, pelaksanaan, hingga evaluasi. Pada tahap pengelolaan ini seluruh isi program kampanye diarahkan untuk membekali dan mempengaruhi aspek pengetahuan, sikap dan keterampilan khalayak sasaran. Ketiga aspek ini dalam literatur ilmiah dipercayai menjadi prasyarat dalam terjadinya perubahan perilaku (Venus, 2009: 16).

Tahap terakhir dalam proses manajemen kampanye ini adalah tahap evaluasi. Venus (2012: 210) mengatakan bahwa evaluasi adalah upaya sistematis untuk menilai berbagai aspek yang berkaitan dengan proses pelaksanaan dan pencapaian tujuan kampanye. Dua aspek dalam definisi tersebut menunjukkan bahwa dalam melakukan evaluasi perlu diperhatikan tentang bagaimana kampanye dilaksankaan dan apa hasil yang dicapai.

Menurut Ostergaard (dalam Venus 2009: 213), evaluasi kampanye dapat dikategorisasi dalam empat level atau tingkatan sebagai berikut; tingkatan kampanye (campaign level), tingkatan sikap (attitude level), tingkatan perilaku (behavior level), dan tingkatan masalah (problem level). Tingkatan kampanye mengetahui apakah khalayak sasaran terterpa kegiatan kampanye yang dilakukan atau tidak.

Metode yang digunakan untuk mendapatkan hasil evaluasi adalah dengan cara survei. Metode ini bukan hanya memberikan berapa persen kira-kira khalayak yang terterpa tetapi juga apakah khalayak memberikan perhatian atau tidak pada pesan (kemampuan kelompok sasaran dalam menyebutkan sumber pesan, 
siapa yang menyampaikan, waktu penayangan atau mungkin warna yang digunakan dalam menyajikan pesan, dan lain-lain).

\section{METODE PENELITIAN}

Penelitian mengenai Kampanye Belkaga oleh Kementerian Kesehatan RI tahun 2015 ini mengacu pada paradigma Positivisme, sebab penelitian ini menggunakan pola pikir deduktif. Paradigma positivisme adalah suatu paradigma yang terorganisasi untuk mengkombinasikan deductive logic dan pengamatan empiris dari perilaku individu, yang berguna secara probablistik menemukan atau memperoleh konfirmasi tentang sebab-akibat yang bisa dipakai untuk memprediksi pola umum dari kegiatan manusia (Neumann, 2005: 140).

Dalam penelitian ini, penulis menggunakan metode deskriptif melalui pendekatan kualitatif yang akan menjelaskan dan menggambarkan fenomena yang terjadi (Rakhmat, 2007: 24). Tujuan penelitian deskriptif kualitatif ini adalah untuk mencari informasi faktual yang detil mengenai gejala yang ada, mengidentifikasi masalah-masalah yang terjadi dan praktikpraktik yang sedang berlangsung, serta membuat komparasi dan evaluasi (Rakhmat, 2007: 27). Penelitian deskriptif hanya memaparkan situasi atau peristiwa. Penelitian ini tidak mencari atau menjelaskan hubungan, tidak menguji hipotesis atau membuat prediksi. (Rakhmat, 2012: 24)

Metode deskriptif adalah suatu metode dalam meneliti status sekelompok manusia, suatu objek, suatu set kondisi, suatu sistem pemikiran, ataupun suatu kelas peristiwa pada masa sekarang. Menurut Whitney (1960), seperti dikutip Nazir dalam buku Metode Penelitian, metode deskriptif adalah pencarian fakta dengan interpretasi yang tepat. Penelitian deskriptif mempelajari masalahmasalah dalam masyarakat, serta tata cara yang berlaku dalam masyarakat serta situasi-situasi tertentu, termasuk tentang hubungan, kegiatankegiatan, sikap-sikap, pandangan-pandangan, serta proses-proses yang sedang berlangsung dan pengaruh-pengaruh dari suatu fenomena. (Nazir, 2009: 54-55)

Teknik sampling yang digunakan penulis dalam penelitian ini adalah teknik purposive sampling. Purposive sampling adalah teknik pengambilan sampel sumber data dengan pertimbangan tertentu.

Pertimbangan tertentu ini misalnya orang tersebut yang dianggap paling tahu tentang apa yang kita harapkan atau mungkin dia sebagai penguasa sehingga akan memudahkan peneliti untuk menjelajahi objek/situasi sosial yang diteliti (Sugiyono 2012: 218). Peneliti memilih orang tertentu, orang yang dinilai paling paham atau yang dipertimbangkan dapat membukakan akses data yang diperlukan, selanjutnya berdasarkan data atau informasi yang diperoleh dari sampel sebelumnya itu, peneliti dapat menetapkan sampel lainnya yang dipertimbangkan akan memberikan data lebih lengkap.

Berdasarkan penjelasan tersebut, maka peneliti memiliki kriteria khusus yang dibuat untuk menentukan narasumber/informan kunci yang sesuai dengan tujuan penelitian untuk menghindari subjektifitas dalam pemilihan sampel. Kriteria khusus tersebut di antaranya adalah: orang-orang yang peneliti anggap berkaitan dengan masalah penelitian, dalam hal ini masalah mengenai penyakit Filariasis/ Kaki Gajah, dan telah memiliki pemahaman serta memiliki peran penting dalam program tersebut; orang-orang yang terlibat langsung dalam pelaksanaan kampanye, minimal selama proses perencanaan berlangsung; orang-orang yang terlibat selama pelaksanaan kampanye; orang-orang yang memiliki kredibilitas di bidang tertentu yang berkaitan dengan Kampanye Belkaga; serta orang-orang yang bersedia dan memiliki waktu luang yang cukup untuk diwawancarai.

Sedangkan untuk teknik keabsahan data, peneliti memilih seorang triangulator untuk memeriksa hasil wawancara yang telah peneliti lakukan dengan informan melalui kriteria tertentu. Triangulator yang peneliti pilih adalah orang yang paham mengenai penyelenggaraan kampanye dan/atau berprofesi di bidang komunikasi, serta pernah terlibat dalam suatu kampanye sebagai panitia pelaksana.

\section{HASIL DAN PEMBAHASAN}


Pada tanggal 1 Oktober tahun 2015, Kementerian Kesehatan RImulai mencanangkan Kampanye Nasional Bulan Eliminasi Kaki Gajah sebagai kegiatan yang dilakukan untuk mengingatkan kembali sekaligus mengajak masyarakat mencegah dan mengendalikan penyakit Kaki Gajah dengan meminum obat Filariasis. Pada tahun 2002, sudah pernah dilakukan pencanangan Belkaga oleh Menkes di Banyuasin, Sumatera Selatan. Namun, saat itu kegiatannya belum diselenggarakan secara nasional dan besar-besaran, sehingga masih banyak daerah endemis Filariasis yang tidak melaksanakannya. Sementara itu, penyebaran penyakit Kaki Gajah atau Flariasis di Indonesia masih sangat mengkhawatirkan. Tercatat, 105 juta penduduk tanah air rentan terserang penyakit tersebut. Untuk itu, Kementerian Kesehatan RI melalui Biro Pusat Komunikasi Publik kembali menggalakkan kegiatan pemberian obat pencegahan filariasis secara massal. Namun, kegiatan tersebut belum efektif dalam mencapai hasil kampanye. Sebab, masih ada warga yang tidak ingin mendatangi pos pengobatan untuk meminum obat sesuai pesan kampanye. Kampanye digunakan karena mengacu pada hasil penelitian bahwa: "hasil penelitian menunjukkan bahwa ada hubungan yang kuat antara kampanye dengan sikap masyarakat terhadap kesehatan diri"'(Citrasiwi, Hafiar, \& Sjoraida, 2017).

Berdasarkan model Ostergaard, tahap pertama dalam model tersebut adalah problem, yaitu tahap untuk mencari tahu masalah apa yang terjadi di lapangan sebelum memutuskan untuk melaksanakan kampanye. Tahap pertama itu disebut Venus sebagai tahap prakampanye atau identifikasi masalah, dalam tahap ini pembuat keputusan atau pelaksana kampanye melihat fakta-fakta yang terjadi dalam lingkungannya sebagai masalah. (Venus, 2009: 15). Mengacu pada tahap tersebut, Kementerian Kesehatan bersama tim dari masing-masing Dinas Kesehatan Kabupaten/Kota telah melakukan riset terlebih dahulu sebelum memutuskan untuk membuat kampanye tentang Kaki Gajah. Pengumpulan informasi berdasarkan Survei data dasar prevalansi mikrofilaria dilakukan untuk menentukan wilayah endemis Filariasis.
Wilayah endemis Filariasis meliputi satuan kabupaten/kota yang ditentukan berdasarkan hasil survei data dasar prevalansi mikrofilaria menunjukkan angka mikrofilaria (mikrofilaria rate) lebih dari 1\%. Secara sederhana, apabila pada suatu daerah terdapat seseorang yang di dalam tubuhnya terdapat cacing filaria, dan di tempat tinggalnya terdapat nyamuk penular yang sesuai, maka daerah sekitarnya adalah daerah penularan. Pelaksana survei adalah Dinas Kesehatan Kabupaten/Kota, atau unit lain di Pusat dan Daerah berkoordinasi dengan Dinas Kesehatan Kabupaten/Kota.

Setelah itu, kampanye Belkaga ini ditentukan dan dibuat rumusan tujuan yang mengacu pada tujuan dari organisasi dunia, yaitu WHO, bahwa pada tahun 2020, seluruh dunia harus sudah eliminasi Filraiasis. Maka tujuan kampanye Belkaga adalah untuk melakukan pengobatan massal dalam rangka pencegahan penyakit Filariasis. Dikutip dari jurnal berjudul Kampanye Program Pemberian ASI Eksklusif: Studi Deskriptif Implementasi Program Peningkatan Pemberian ASI Eksklusif di Kota Administrasi Jakarta Utara, tujuan kampanye program PP ASI Eksklusif di Kota Administrasi Jakarta Utara dibuat berdasarkan prioritas yang pasti dan paling utama, yaitu tercapainya MDGs 2015. Hal ini dikaitkan dengan teori tujuh tujuan utama kampanye PR menurut Gregory ( Ekawati, S. Dkk. 2015).

Helena,salah satu informan dari Kementerian Kesehatan RI, mengatakan bahwa tujuan dilaksanakannya kampanye Belkaga adalah untuk melakukan pemutusan transmisi yang efektif di daerah endemis bahkan di Indonesia. Disamping itu juga untuk mengejar target eliminasi Filariasis di tahun 2020 melalui kegiatan pengobatan massal tersebut. Helena juga menjelaskan bahwa kegiatan ini merupakan sebuah cara yang efisien untuk mencapai tujuan dari eliminasi Filariasis itu. Dinas Kesehatan Kabupaten Bogor pun telah menegaskan bahwa tujuan penyelenggaraan kampanye Belkaga adalah untuk mencapai target cakupan minimal 75\% sehingga dapat dikatakan tujuan yang mereka buat berorientasi kepada hasil. Pelaksana kampanye akan fokus pada tujuan utama tersebut sehingga bagaimanapun caranya 
yang terpenting adalah tercapainya target cakupan pengobatan.

Tahap kedua yaitu pengelolaan kampanye yang dimulai dari perancangan, pelaksanaan, hingga evaluasi. Dalam melakukan perancangan kampanye ini riset perlu dilakukan untuk mengidentifikasi karakteristik khalayak sasaran untuk dapat merumuskan pesan, aktor kampanye, saluran hingga teknis pelaksanaan kampanye yang sesuai. (Venus, 2009: 16). Langkah identifikasi segmentasi sasaran dilakukan agar kegiatan atau program yang disusun tepat sasaran. Perlu dilakukan penetapan khalayak melalui identifikasi khalayak mana saja yang mestinya mengetahui kampanye serta peduli akan isu yang diangkat oleh kampanye tersebut. Segmentasi sasaran kampanye dilakukan Kemenkes berdasarkan pendataan sasaran pengobatan yang telah dibuat berdasarkan prosedur warga wajib minum obat. Seluruh warga yang tinggal di daerah endemisitas merupakan sasaran kampanye juga. Kementerian Kesehatan RI tidak memiliki target khalayak yang jelas antara masyarakat mana yang memiliki kepentingan untuk menerima pesan kampanye, apakah mereka yang sehat, teridentifikasi penyakit Filariasis ataupun terduga tertular virus Filariasis, dan yang benar-benar terjangkit penyakit tersebut sehingga semua mempunyai pembobotan yang sama.

Setelah mengenal khalayak dan situasinya, maka langkah selanjutnya ialah menyusun pesan, yaitu menentukan tema dan materi. Hal ini juga telah disebutkan dalam jurnal berjudul Strategi Komunikasi Pada Kampanye Perlindungan Orangutan Oleh LSM Centre for Orangutan Protection (COP) di Samarinda, Klimantan Timur, bahwa pesan untuk kegiatan School Visit dibuat berbeda sesuai dengan tingkat sekolah yang dituju. Hal tersebut sesuai dengan konsep pesan yang tertulis pada bab teori dan konsep yang menyebutkan bahwa pesan tidaklah berdiri sendiri, karena pesan yang baik harus sesuai, terutama, dengan karakteristik khalayak sasaran, dan efek yang diharapkan (Misnawati, I. T. , 2013).

Pada tiap kampanye, tentunya harus ada pesan yang disampaikan kepada target sasaran. Maka,Kementerian Kesehatan pun melakukan perumusan pesan agar tujuan yang ingin disampaikan dapat diterima dengan baik. Pertama, Kemenkes menentukan tema besar dari kampanye Belkaga, yaitu, "Minum Obat Bersama untuk Indonesia Bebas Penyakit Kaki Gajah."

Menurut Venus (2004: 71), hal-hal seperti ilustrasi kejadian, visualisasi kejadian, fakta, dan kejadian bersejarah dalam sebuah pesan sangat mempengaruhi perubahan sikap orang yang menerima pesan tersebut. Pada sisi lain, pelaku kampanye juga harus melihat pesan dari pendekatan emosional, rasa takut, kreativitas, dan humor pada saat penyampaian pesan. Pada kampanye Belkaga, visualisasi digunakan dengan mengekspos foto dan video dari warga yang sudah terjangkit penyakit Kaki Gajah atau para penderita yang dampaknya sudah terlihat parah untuk menyentuh sisi emosional publik. Konten gambar dan video tersebut terutama dikhususkan untuk masyarakat yang tingkat pendidikannya menengah ke bawah, sedangkan masyarakat yang tingkat pendidikannya lebih tinggi sudah cukup diberi penjelasan dengan tulisan saja. Pendekatan pesan rasa takut akan terjangkit bahaya virus penyakit Kaki Gajah menjadi strategi pengolahan pesan yang lebih efektif untuk menimbulkan perubahan perilaku dalam kampanye Belkaga.

Helena menjelaskan bahwa pesan yang ingin disampaikan kepada masyarakat adalah mengenai pentingnya meminum obat pencegahan penyakit Filariasis tersebut. Masyarakat diimbau untuk mengetahui dan menyadari bahwa tujuan pemberian obat itu adalah untuk memutus transmisi virus Filariasis, bukan hanya sekadar obat yang dibagikan secara gratis. Hal itu akan menjadikan masyarakat seorang warga negara yang baik karena patuh terhadap program pemerintah selain demi menjaga kesehatan dirinya sendiri. Pembentukan pesan ini sudah dilakukan secara intensif di awal tahun oleh tim dari pusat promosi dan komunikasi di Kemenkes bekerja sama dengan WHO, lembaga donor, dan juga mengundang ahli-ahli komunikasi lainnya yang sudah berpengalaman. Secara khusus, pesan yang akan disampaikan dalam kampanye 
membahas mengenai pemilihan kata-kata, logo, materi dan bahan-bahan KIE.

Kementerian Kesehatan RI memilih beberapa artis dalam membantu menyampaikan pesannya, yaitu Cak Lontong dan Jarwo Kwat sebagai talentuntuk Iklan Layanan Masyarakat mengenai Belkaga dan juga Nycta Ghina sebagai penyampai pesan dalam acara talkshow di salah satu stasiun televisi swasta. Mereka dipilih berdasarkan tingkat kepeduliannya terhadap kesehatan masyarakat selain juga karena dikenal baik oleh masyarakat Indonesia. Pada umumnya, faktor pokok yang harus diperhatikan dalam menyeleksi pelaku kampanye adalah kesesuaian tokoh tersebut dengan objek kampanye, media yang digunakan, dan kredibilitas yang bersangkutan di mata publik. Objek kampanye umumnya dijadikan dasar pertimbangan pertama dalam menetapkan penyampai pesan kampanye. (Venus, 202: 2012) Pemilihan public figuresebagai penyampai pesan dilakukan karena orang yang sudah dikenal baik oleh masyarakat diharapkan dapat lebih memotivasi dan menarik minat khalayak untuk mendengar dan menuruti ajakan mereka sesuai isi pesan yang ingin disampaikan oleh Kementerian Kesehatan kepada khalayak. Dalam suatu kampanye tentunya harus ada komunikator yang menyampaikan pesan atau konten dalam suatu kampanye. Dan untuk mengetahui efektivitas suatu media kampanye, maka peran dan siapa komunikatornya pun akan menjadi pengaruh penting. Apakah komunikator tersebut merupakan orang yang berkredibilitas dalam media kampanye yang digunakan. Apakah komunikator tersebut mampu mewakili pesan yang ingin disampaikan. Apakah komunikator tersebut dapat menggunakan media yang dipilih sehingga media kampanye tersebut menjadi media yang efektif. Pernyataan tersebut didapatkan dari jurnal berjudul Kampanye Produk Minuman Melalui Games Interaktif (Wicaksana, R. R. , 2015).

Strategi Kemenkes dalam mewujudkan tujuan kampanye Belkaga yaitu dengan menyampaikan hal-hal mengenai kasus Filariasis yang terjadi di Indonesia dan juga menggerakkan masyarakat untuk mendatangi pos POPM Filariasis pada saat pelaksanaannya.
Selanjutnya, untuk dapat mewujudkan strategi tersebut, Kemenkes menentukan taktik yang akan dilakukan, yaitu dengan publikasi melalui media elektronik, cetak, dan online. Taktik lainnya yaitu dengan melakukan sosialiasi mengenai kampanye Belkaga untuk meningkatkan pengetahuan, sikap dan perilaku masyarakat dengan memberikan informasi yang jelas tentang kegiatan POPM Filariasis, sehingga semua penduduk minum obat pencegahannya. Kementerian Kesehatan tentunya melibatkan kader kesehatan dan pihak lainnya untuk mengajak masyarakat untuk berpartisipasi dalam kampanye Belkaga tersebut. Pemberian informasi melalui sosialisasi ini termasuk yang penting dilakukan, tetapi juga tidak mudah untuk dapat disampaikan ke beberapa pihak tertentu. Seperti juga dijelaskan dalam jurnal berjudul Aktivisme Sosial Melalui Penggunaan Media Sosial Studi Kasus Asosiasi Ibu Menyusui Indonesia (AIMI), yang menyatakan bahwa di awal pendirian Pengurus AIMI mengakui bahwa seringkali sulit meyakinkan pihak-pihak lain bahwa AIMI dan konselor laktasi non medis juga dapat membantu memberikan kontribusi nyata serta memiliki otoritas untuk membicarakan isu ASI eksklusif dan kesehatan ibu dan anak. Resistensi tidak hanya datang dari tenaga-tenaga kesehatan yang merasa AIMI tidak memiliki otoritas baik secara akademis maupun professional untuk berkiprah di sektor kesehatan, namun juga harus menghadapi resistensi masyarakat yang belum paham mengenai Konselor Laktasi non medis yang memiliki sertifikasi khusus untuk membantumemberikan konseling hingga derajat tertentu(Hartoyo,N. M. dkk. (2015).

Advokasi juga dilakukan untuk memperoleh dukungan pelaksanaan kegiatan POPM Filariasis oleh bupati/walikota setempat. Taktik dengan publikasi oleh Kemenkes juga dilakukan melalui SMS Blast, yaitu SMS yang disebar berisi ajakan untuk mendatangi pos minum obat pencegahan Filariasis pada tanggal 1 Oktober. Kemenkes RI bekerjasama melalui beberapa perusahaan provider Telkomsel dan juga Kementerian lainnya. Taktik dengan media publikasi ini juga tertera dalam buku Kampanye Public Relations oleh Ruslan yang mengatakan 
bahwa melakukan kampanye untuk penyebaran pesan (message) melalui proses publikasi suatu berita melalui kerjasama dengan berbagai media massa. (Ruslan, 2005: 54)

Para ahli kampanye sepakat bahwa rencana kampanye, khususnya desain pesan, haruslah diujicoba terlebih dahulu untuk menentukan apakah cara ini memberikan hasil yang diharapkan atau tidak. Jika hasilnya negatif, maka dapat disusun kembali rencana lain dan jika hasilnya positif, maka rencana tersebut dapat dilanjutkan ke tahap tindakan.

Pada umumnya, pengajuan rencana tidaklah dilakukan terhadap semua aspek yang ada dalam rancangan kampanye, melainkan hanya beberapa hal yang memerlukan investasi waktu atau biaya yang besar. Dalam pengujian rencana ini, perlu ditekankan lagi, unsur pesan kampanye biasanya menjadi fokus utama. Hal ini dapat dimengerti mengingat pesan adalah kunci untuk membangun kesamaan persepsi antara pelaksana dan khalayak sasaran kampanye. (Venus, 2007: 204-205). Oleh karena itu, Kemenkes melakukan uji coba terlebih dahulu terhadap pesan yang akan disampaikan dalam kampanye Belkaga. Pesan kampanye yang diujicobakan dilakukan kepada dua kalangan masyarakat sebagai bahan perbandingan. Sebab, bisa terjadi perbedaan pendapat antara masyarakat dari perkotaan dan dari pedesaan. Maka, diambillah dua daerah pedesaan dan dua daerah perkotaan yang mewakili untuk ditanya pendapatnya mengenai pesan kampanye.

Kampanye selalu dilaksanakan dalam rentang waktu tertentu. Membuatperencanaan waktu kampanye sangat penting dilakukan oleh seorang PR. Menurut Gregory (2000), ada dua faktor utama yang saling berkaitan yang harusdiamati ketika mempertimbangkan skala waktu. Pertama, tenggat waktu (deadline) harus diidentifikasi sehingga tugas-tugas yang dihubungkan dengansuatu proyek dapat diselesaikan tepat waktu. Kedua adalah sumber daya yangtepat perlu dialokasikan sehingga tugas - tugas yang ada dapat diselesaikan. Dinas Kesehatan mulai menyusun time schedule untuk kegiatan yang dimulai sekitar bulan Maret untuk melakukan persiapan. Kementerian Kesehatan menyusun tabel perencanaan waktu berisi jadwal yang akan dilakukan dari awal hingga akhir kampanye. Bekerjasama dengan tim dari Dinas Kesehatan Kabupaten/Kota, jadwal disusun berdasarkan bulan dan harian sesuai dengan kegiatan yang akan dilakukan dalam satu kota atau jangka waktu pelaksanaan kampanye secara keseluruhan.

Pelaksanaan kegiatan POPMF sendiri dilaksanakan mulai bulan Agustus hingga bulan Oktober. Pencanangannya baru dimulai sejak tanggal 1 Oktober dan selama sebulan penuh di bulan tersebut pelaksanaan pemberian obat dilakukan di desa masing-masing di Indonesia yang merupakan daerah endemis. Sementara itu persiapannya sudah dilakukan sejak dua bulan sebelum pelaksanaan POPMF, seperti advokasi, sosialisasi, distribusi obat, hingga pelatihan petugas kesehatan. Pada tenggat waktu yang sama, hal ini dilakukan pada tahun-tahun berikutnya berturut-turut hingga tahun 2019 . Kementerian Kesehatan bekerja sama dengan berbagai pihak dalam menjalankan kampanye Belkaga, sebab kegiatan ini merupakan kegiatan nasional yang tentunya perlu melibatkan banyak personil sehingga tidak mungkin jika Kemenkes bisa menjalankannya sendiri. Kegiatan ini dilakukan oleh sumber daya manusia yang memiliki keahlian dan kompetensi sesuai ketentuan peraturan perundang-undangan. Beberapa di antaranya seperti Kemendagri, Kemkominfo, SKPD, para tenaga kesehatan, dan satuan dinas-dinas instansi lainnya turut berpartisipasi dalam melaksanakan kampanye Belkaga.

Selain perencanaan waktu, hal penting lainnya yang harus ada dalam perencanaan kampanye adalah sumber daya. Sumber daya sendiri di sini dikelompokkan menjadi tiga bagian yaitu sumber daya manusia, biaya dan peralatan. Kementerian Kesehatan bekerja sama dengan berbagai pihak dalam menjalankan kampanye Belkaga, sebab kegiatan ini merupakan kegiatan nasional yang tentunya perlu melibatkan banyak personil sehingga tidak mungkin jika Kemenkes bisa menjalankannya sendiri. Kegiatan ini dilakukan oleh sumber daya manusia yang memiliki keahlian dan kompetensi sesuai ketentuan peraturan perundang-undangan. Beberapa di 
antaranya seperti Kemendagri, Kemkominfo, SKPD, para tenaga kesehatan, dan satuan dinasdinas instansi lainnya turut berpartisipasi dalam melaksanakan kampanye Belkaga.

Menyusun anggaran adalah salah satu pekerjaan penting yang harus dilakukan sebagai bagian dari kegiatan kampanye. Penyusunan anggaran diperlukan untuk mengetahui seberapa banyak dana diperlukan dalam rangka membiayai suatu program humas. Dalam hal ini, pihak Kementerian Kesehatan RI mendapatkan bantuan anggaran dari APBN (Anggaran Pendapatan dan Belanja Negara), APBD (Anggaran Pendapatan dan Belanja Daerah), Bank yang bekerjasama dengan Kemenkes, serta perusahaan lain yang turut menjadi donatur dalam kegiatan kampanye Belkaga atau sumber lain yang sah sesuai dengan ketentuan perundang-undangan. Alokasi biaya ini dibuat dalam laporan tertulis ke dalam laporan keuangan yang nantinya akan dipertanggungjawabkan.

Terakhir dan tidak kalah penting adalah sumber daya peralatan. Suatu kampanye dapat dikatakan tidak berjalan secara efektif kecuali bila didukung oleh peralatan yang tepat. Maka dari itu pengalokasian dana operasional harus didasarkan efektivitas dan efisiensi. Dalam hal ini Kementerian Kesehatan melakukan persiapan logistik dan segala kebutuhan kegiatan setelah diketahui daerah mana yang akan melaksanakan POPMF. Peralatan yang dibutuhkan tersebut di antaranya dapat berupa jumlah obat yang dibutuhkan, jumlah bahanbahan KIE, buku saku kader, leaflet, poster, dan lain sebagainya. Namun, ternyata masih terdapat kekurangan anggaran untuk mencetak bahan KIE sebanyak-banyaknya. Beberapa daerah bahkan memfotokopi sendiri brosur dan semacamnya untuk dibagikan kembali ke warga lainnya. Buku saku kader yang seharusnya dimiliki oleh para kader kesehatanpun jumlahnya terbatas, sehingga tidak jarang ada kader yang tidak mengetahui bahwa buku saku kader tersebut ada.

Proses pelaksanaan pada program ini, dimulai dari penentuan siapa saja yang akan terlibat sebagai pelaksana kampanye. Pertama, Kementerian Kesehatan menentukan koordinator sebagai pengelola kampanye dengan melatihnya terlebih dahulu. Sehingga, pengelola tersebut dapat mengatur jalannya kegiatan secara keseluruhan. Koordinator kampanye bertugas mengatur kegiatan bersama para tim yang bekerja di bawah perintahnya. Sementara itu pelatihan petugas juga dilakukan terhadap petugas puskesmas dan kader-kader kesehatan. Salah satu kebutuhan penting adalah pengadaan pelatihan-pelatihan untuk membangun kemampuan-kemampuan pihak-pihak yang bermitra agar bisa beroperasi secara efektif. Hal ini dijelaskan pula dalam jurnal berjudul Model Kemitraan PT. Holcim Indonesia Tbk. Pembentukan tim untuk pelaksanaan kampanye Belkaga tidak lagi dilakukan seleksi khusus sebab seluruh divisi yang berkaitan dengan penyelenggaraan porgram sudah otomatis menjalankan tugas sesuai bagiannya masingmasing (Nassaluka, Hafiar, \& Priyatna, 2016). Selanjutnya dilakukan pelatihan terhadap petugas, khususnya petugas Filariasis yang ada di Puskesmas dan juga petugas kader kesehatan, sebab mereka adalah orang yang bertanggung jawab langsung menangani pos pengobatan pada saat pelaksanaan POPMF. Pelatihan tersebut penting agar proses pelaksanaan secara teknis dapat berjalan sesuai prosedur yang telah ditetapkan. Seperti juga disebutkan dalam sebuah jurnal berjudul Emergency Response Plan Garuda Indonesia, menjaga sesuatu biasanya lebih susah daripada mendapatkannya. Untuk menjaga pemahaman orang-orang yang terlibat di dalam Emergency Response Plan, Garuda Indonesia secara berkala mengadakan simulasi krisis yang bertujuan untuk menjaga pemahaman, pengetahuan, dan flow kerja pada saat menangani krisis yang bisa terjadi kapan pun (Yogi, G. P. dkk 2016).

Segera setelah personel direkrut, mereka harus mengikuti pelatihan, baik yang bersifat teknis atau nonteknis, yang berkaitan dengan berbagai aspek dan proses yang akan dijalankan selama kampanye berlangsung. (Venus, 2012: 200). Pelatihan ini lebih kepada bagaimana teknis pelaksanaan petugas dalam memberikan obat kepada warga atau sasaran yang mendatangi pos. Pelatihan kader ini agar kader yang turun membantu Kementerian Kesehatan mengetahui 
apa yang harus mereka kerjakan.

Selanjutnya, kampanye Belkaga harus dipublikasikan kepada khalayak sasaran agar mereka mengetahui acara tersebut. Oleh karena itu, publikasi dilakukan melalui media cetak dan elektronik. Iklan layanan masyarakat, talkshow di radio dan tv lokal, surat kabar, penempelan stiker, pemasangan spanduk, penyebaran brosur/leaflet dan poster semua dilakukan sebagai cara untuk mempublikasikan kampanye Belkaga. Selanjutnya, kampanye Belkaga harus dipublikasikan kepada khalayak sasaran agar mereka mengetahui acara tersebut. Kementerian Kesehatan juga menggunakan media sosial seperti facebook dan twitter sebagai tambahan dalam menyampaikan segala informasi mengenaiBelkaga. Kementerian Kesehatan RI perlu menyeleksi media terlebih dahulu dengan melakukan berbagai pertimbangan untuk menentukan media mana yang dapat digunakan sebagai saluran kampanye. Proses seleksi media sosial ini juga dijelaskan dalam jurnal berjudul Literasi Media Sebagai Strategi Komunikasi Tim Sukses Relawan Pemenangan Pemilihan yang menyatakan bahwa proses pemilihan media sosial yang dipergunakan dalam pemenangan presidenJokowi di kota Bandung ini merupakansuatu proses yang cukup memakan waktudan pikiran para anggota tim sukses relawan. Butuh lima kali pertemuan antara anggotatimses untuk membahas masalah tersebut,banyaknya anggota yang berbeda pendapatmenjadi salah satu kendala apakah mediasosial secara terus menerus akan efektifdalam penggunaannya (Senova, A, 2016).

Strategi media relations merupakan sekumpulan kebijakan dan taktik yang sudah ditetapkan untuk mencapai tujuan kegiatan media relations khususnya, dan public relations yang tentunya sebagai peranan yang diacukan pada tujuan perusahaan. Pernyataan tersebut didapat dari jurnal berjudul Strategi Media Relations PT Pelabuhan Tanjung Priok dalam Menanggapi Krisis Febriansyah, R. A. dkk. (2016).

Pertimbangan pemilihan media terlebih dahulu disesuaikan dengan anggaran yang dimiliki. Sebisa mungkin publikasi dilakukan melalui media yang terjangkau biaya dan dapat menyasar khalayak dengan tepat. Semua media dikerahkan agar dapat menjangkau seluruh kalangan, sebab pesan kampanye harus dapat diterima oleh seluruh masyarakat. Namun, Dinas Kesehatan Kabupaten hanya bisa menentukan media yang telah dipilahkan oleh pusat, yaitu Kementerian Kesehatan RI, berdasarkan anggaran yang dimiliki.

Meskipun demikian, pertimbangan mengenai penggunaan media resmi dan jumlah pemirsa juga dilakukan. Selain itu, penayangan iklan maupun acara talkshow hanya mendapat slot yang tidak banyak karena jumlah anggaran yang terbatas. Media tersebut di antaranya JakTV, TVRI, MetroTV, RRI, TVOne, detikcom, kompas. com, BaliTV, TV Antara dan lain-lain. Dijelaskan pula oleh dr. Intan Widayati, bahwa di Kabupaten Bogor juga melakukan publikasi melalui radio-radio lokal serta surat kabar dengan terlebih dahulu mengundang wartawan untuk mendatangi Press Conference yang diselenggarakan satu bulan sebelum pelaksanaan.

Beberapa faktor yang perlu untuk dipertimbangkan dalam pemilihan media diantaranya: jangkauan media, tipe dan ukuran besarnya publik, biaya, waktu, dan tujuan serta objek kampanye. Di samping itu, faktor lain yang juga perlu mendapat perhatian adalah karakteristik publik, baik secara demografis, psikografis, maupun geografis. Pola penggunaan media publik(media habit) juga harus diperhitungkan untuk memastikan media apa yang biasanya digunakan publik (Venus, 2012: 203).

Tahapan pengelolaan kampanye ini ditutup dengan melakukan evaluasi mengenai efektivitas program yang telah dilaksanakan. Sebagai sebuah kegiatan yang terprogram dan direncanakan dengan baik, maka segala tindakan dalam kampanye harus dipantau agar banyak kendala yang dihadapi untuk membuat tindakan kampanye tetap pada jalur yang benar. Untuk itu, harus dipahami bahwa tindakan kampanye bukanlah tindakan yang kaku dan parsial. (Venus, 2007: 205) Evaluasi dan tinjauan terhadap program kampanyemerupakan salah satu bagian dari perencanaan kampanye yang tidak 
bolehterlupakan. Evaluasi adalah komponen terakhir dari rangkaian proses pengelolaan kampanye. Bentuk evaluasi pengelolaan kampanye yang dilakukan oleh Kementerian Kesehatan RI adalah dengan melakukan survei dan wawancara langsung. Setelah kegiatan POPMF selesai dilakukan oleh suatu daerah, maka tim independen yang tidak berkaitan dengan dinas setempat akan turun ke lapangan mendatangi warga yang ada di daerah tersebut untuk diwawancara mengenai pengetahuannya akan Kaki Gajah maupun kesediaannya hadir pada pos pengobatan. Kementerian Kesehatan RI melakukan evaluasi dengan melakukan pemantauan melalui tim-tim yang bekerja di bawahnya. Masing-masing tim dari kabupaten/ kota memiliki petugas tersendiri untuk dapat memantau pelaksanaan dengan mendatangi langsung daerah yang sedang melaksanakan program kampanye Belkaga, yaitu program POPMF. Pemantauan tersebut nantinya dibuat laporan yang kemudian diserahkan ke pusat untuk dievaluasi apa saja kekurangan dan kendala selama pelaksanaan.

Sementara itu dalam jurnal berjudul Implementasi Kegiatan Corporate Communication Oleh Divisi Corporate Secretary PT Biofarma (Persero) dijelaskan bahwa perihal monitoring dan evaluasi program, disusun oleh tim monitoring/evaluasi Bio Farma dengan berpedoman pada Perencanaan Program dan Indikator Kinerja Program. Monitoring dilakukan melalui kunjungan tim Bio Farma ke lapangan, sementara evaluasi meliputi laporan semesteran dan laporan akhir tahun yang disusun Mizumi Koi (Rakhmawati \& Sani, 2016).

Tahap ketiga dalam manajemen kampanye, yaitu tahap evaluasi kampanye. Tahap ini merupakan langkah akhir yang harus dilakukan dalam sebuah kampanye untuk mengevaluasi kampanye secara keseluruhan. Evaluasi kampanye diartikan sebagai upaya sistematis untuk menilai berbagai aspek yang berkaitan dengan proses pelaksanaan dan pencapaian tujuan kampanye. Secara singkat penilaian terhadap proses implementasi rancangan kampanye dapat dilakukan dengan menganalisis catatan harian kampanye yang berisi berbagai data dan fakta sebagai hasil proses pemantauan (monitoring), pengamatan lapangan dan wawancara yang dilakukan untuk mendapatkan umpan balik. Dijelaskan pula dalam jurnal berjudul Strategi Promosi Penjualan Lazada. co. id bahwa Hasil evaluasi strategi promosi penjualan melalui website yang dilakukan oleh lazada Indonesia hanyalah sebagai pembelajaran untuk tidak mengulangi kesalahan yang sama dan untuk memperbaiki kegiatan promosi penjualan yang akan diadakan selanjutnya (Reza, 2016).

Proses evaluasi yang dilakukan Kementerian Kesehatan difokuskan pada dua hasil, yaitu evaluasi dari metode kampanye dan evaluasi mengenai penemuan kasus Kaki Gajah. Kemenkes melaksanakan proses ini seperti yang dilakukan pada model Ostergaard, evaluasi mengenai pesan yang disampaikan apakah dapat diingat, diterima dan dipublikasikan. Hal itu dilakukan dengan survei dan wawancara dengan mendatangi penduduk secara langsung oleh tim independen.

Kementerian Kesehatan RI membagi proses evaluasi ke dua bagian, yaitu evaluasi mengenai efektivitas metode kampanye untuk mengetahui KAP (Knowledge, Attitude, Practice) masyarakat dan evaluasi terhadap active case finding. Berdasarkan hasil wawancara peneliti kepada beberapa pelaksana kampanye Belkaga, ada beberapa tolok ukur yang akan dijadikan acuan dalam menilai keberhasilan program. Beberapa tolok ukur tersebut yaitu, keikutsertaan masyarakat dalam POPM, angka cakupan pengobatan minimal $65 \%$, serta pemahaman masyarakat terhadap pesan kampanye.

Biasanya evaluasi terhadap suatu proses dapat berupa tolok ukur suatu pencapaian keberhasilan atau juga kegagalan selama berlangsungnya kegiatan kampanye baik dalam jangka pendek atau jangka panjang, termasuk mengevaluasi pemanfaatan, dan hingga sejauh mana kegiatan kampanye telah menjadi liputan media massa, serta hasil-hasil apa saja yang telah dicapai. (kampanye pemberian ASI)

Sementara itu evaluasi terhadap Actice Case Finding, adalah sebuah proses dan tatalaksana penemuan kasus Kaki Gajah baru 
di masyarakat. Terselenggaranya kegiatan kampanye Belkaga yang terencana dengan baik terhadap seluruh penduduk sasaran di Daerah Endemis Filariasis (Kabupaten/Kota Endemis Filariasis) dengan cakupan lebih 85\% jumlah penduduk sasaran pengobatan dan $65 \%$ dari jumlah penduduk total, sehingga dapat menurunkan angka mikrofilaria rate menjadi $<1 \%$.

Menurut Frank Jefkins (Jefkins, 2004: 129), hasil evaluasi dapat dibagi menjadi dua, yaitu hasil kualitatif dan hasil kuantitatif. Pertama yaitu hasil kualitatif. Pada umumnya hasil-hasil dari suatu kegiatan PR bersifat kualitatif. Artinya, hasil tersebut tidak bisa diukur secara statistik, melainkan diukur melalui pengalaman dan perbandingan nyata. Berdasarkan hal ini, Kementerian Kesehatan mengevaluasi kampanye dengan melakukan assessment coverage survey untuk mengetahui sejauh mana pesan kampanye sampai dan dapat diterima oleh khalayak sasaran. Evaluasi tersebut kemudian akan memberikan hasil berupa tingkat pemahaman masyarakat terhadap pesan dan perilaku serta tindakan mereka dalam kegiatan kampanye tersebut.

Kedua, hasil kuantitatif. Secara sederhana, hasil kuantitatif adalah suatu hasil yang bisa diukur secara statistik berdasarkan angka-angka. Kementerian Kesehatan juga menggunakan hasil kuantitatif untuk mengevaluasi hasil kampanye dengan cara menghitung total cakupan pemberian obat pencegahan dalam suatu daerah untuk mengetahui berapa jumlah total khalayak sasaran yang mendatangi pos pengobatan pada saat POPMF diselenggarakan.

Berdasarkan dua hal tersebut, dapat dikatakan bahwa Kementerian Kesehatan RI sudah melakukan evaluasi baik dari segi kualitatif maupun kuantitatif. Dijelaskan pula oleh Jefkins (Jefkins, 2004) yang menyatakan bahwa evaluasi juga perlu dilakukan dengan mengumpulkan pendapat yang nantinya digunakan untuk mengetahui pendapat khalayak tentang program yang berlangsung dan dampak yang mereka rasakan setelah mengikuti program tersebut. Hal ini bisa dilakukan dengan cara membagikan kuisioner atau melakukan wawancara secara langsung terhadap warga yang datang ke pos POPMF.

\section{SIMPULAN}

Pada tahap pra kampanye, penentuan daerah endemis dilakukan melalui pengumpulan informasi berdasarkan survey dasar atau Survey Based Line oleh Kementerian Kesehatan RI. Perumusan tujuan kampanye oleh Kementerian Kesehatan RI berorientasi pada hasil saja, yakni untuk mengejar target eliminasi Filariasis di tahun 2020 dengan melakukan pengobatan massal dalam rangka pencegahan penyakit Filariasis.

Pada tahap selanjutnya yaitu pengelolaan kampanye, Kementerian Kesehatan melakukan tiga tahapan lagi yang terdiri atas perancangan, pelaksanaan, dan evaluasi. Pada perancangan kampanye, hal yang dilakukan adalah menentukan publik sasaran kampanye. Segmentasi sasaran yang dilakukan oleh Kemenkes dilakukan berdasarkan pendataan sasaran pengobatan. Strategi yang digunakan oleh Kemenkes adalah menyampaikan kasuskasus Filariasis di Indonesia dan menggerakkan masyarakat untuk mendatangi pos POPM Filariasis dengan taktik publikasi melalui berbagai media, sosialisasi oleh opinion leader, merekrut volunteer, dan melalui persuasi personal.

Pada pelaksanaan kampanye, Kemenkes tidak melakukan seleksi personil, namun tetap dilakukan pelatihan baik terhadap pengelola maupun petugas puskesmas dan kader kesehatan. Pelatihan tersebut hanya fokus kepada teknis pemberian obat serta informasi mengenai POPMF secara umum, namun tidak berisi anjuran mengenai cara menyampaikan informasi yang sudah didapat kepada masyarakat awam yang menjadi target sasaran minum obat mereka. Selanjutnya, Publikasi dilakukan melalui televisi, radio, surat kabar, media online, SMS Blast, brosur, banner dan lain-lain. Namun, terdapat keterbatasan bahan penyebaran informasi termasuk buku saku kader yang seharusnya dimiliki oleh tiap kader kesehatan. Media yang dipilih pun disesuaikan dengan anggaran yang terbatas.

Tahap terakhir, Kementerian Kesehatan 
melakukan evaluasi dengan dua cara. Kemenkes melakukan evaluasi dengan melaksanakan assesment coverage survey, yaitu survey kepada masyarakat cakupan atau dengan kata lain yang telah mengikuti program POPM.

Kementerian Kesehatan RI juga melakukan evaluasi terhadap Actice Case Finding, yaitu sebuah proses dan tatalaksana penemuan kasus Kaki Gajah baru di masyarakat.

Berdasarkan seluruh simpulan tersebut, penulis memberi saran sebagai berikut. Sebaiknya, Kementerian Kesehatan RI menyesuaikan penyampaian pesan dengan klasifikasi khalayak sasaran berdasarkan warga yang sehat atau tidak teridentifikasi penyakit, warga yang teridentifikasi penyakit atau terduga tertular virus Filariasis, serta warga yang memang sedang menderita penyakit Filariasis.

Kementerian KesehatanRI seharusnya menyasar media massa dengan melakukan riset terlebih dahulu mengenai penggunaan media di kabupaten/kota yang menjadi sasaran kampanye. Pola penggunaan media publik (media habit) juga harus diperhitungkan untuk memastikan media apa yang biasanya digunakan publik.

Pelatihan petugas kader sebaiknya tidak hanya mengenai teknis pelaksanaan pemberian obat saja, tetapi juga diajarkan bagaimana cara untuk menyampaikan informasi sejelas-jelasnya mengenai Belkaga ataupun POPMF agar tidak terjadi kesalahpahaman dan tidak ada lagi isu buruk mengenai efek samping penggunaan obat.

\section{DAFTAR PUSTAKA}

BPOM RI. (2015). Canangkan belkaga untuk indonesia sehat dan bebas kaki gajah. Diakses dari https://www.pom.go.id/ new/view/more/berita/9335/CanangkanBelkaga-Untuk-Indonesia-Sehat-danBebas-Kaki-Gajah. html

Buku Saku Dokter. (2013). Filariasis. Diakses dari http://bukusakudokter. org/2013/04/12/ filariasis/ pada Rabu, 14 Oktober 2015

Citrasiwi, G., Hafiar, H., \& Sjoraida, D. F. (2017). Pembentukan sikap masyarakat terhadap kesehatan diri melalui kampanye 10 perilaku hidup bersih dan sehat. Jurnal
Visi Komunikasi, 14/2, 136-145.

Data statistik divisi Dermatologi umum Departemen Ilmu Kesehatan Kulit dan Kelamin FKUI/RSCM. Terdapat 1 pasien limfedema akibat filariasis sepanjang tahun 2003-2005.

Febriansyah, R. A. dkk. (2016). Strategi media relations pt pelabuhan tanjung priok dalam menanggapi krisis. Jurnal Kajian Komunikasi, Vol. 4, No. 2, Desember 2016: 229-242

Ekawati, S. Dkk. (2015). Kampanye program pemberian asi eksklusif: studi deskriptif implementasi program peningkatan pemberian asi eksklusif di kota administrasi jakarta utara. Kalbisocio. Vol. 2 No. 1, 1-10

Gregory, A. (2004). Perencanaan dan manajemen kampanye public relations (edisi kedua). Jakarta: Penerbit Erlangga.

Hartoyo, N. M. dkk. (2015). Aktivisme sosial melalui penggunaan media sosial studi kasus asosiasi ibu menyusui indonesia (aimi). Jurnal Kajian Komunikasi, Vol. 3, No. 1, Juni 2016: 1-11

Infodatin (Pusat Data dan Informasi Kementrian Kesehatan RI) Filariasis. (2014). Filariasis. Diakses dari http: //www. depkes. go. id/ resources/download/pusdatin/infodatin/ infodatin-filariasis. pdf

Juknis Juklak Filariasis 2015 Pemkab Bogor

Misnawati, I. T. (2013). Strategi komunikasi pada kampanye perlindungan orangutan oleh lsm centre for orangutan protection (cop) di samarinda, kalimantan timur. eJournal Ilmu Komunikasi, Vol. 1 No. 4 , 135-149

Nassaluka, E. U. R., Hafiar, H., dan Priyatna, C. C. (2016). Model kemitraan pt holcim tbk. PRofesi Humas. Vol. 1, No. 1, Agustus 2016: 22-34

Nazir, M. (2009). Metode Penelitian. Jakarta: Ghalia Indonesia.

Neuman, W. (2005). Lawrence, Basic of Social Reasearch: Qualitative and Quantitative Approaches, Pearson Education Inc, Boston.

Rakhmat, J. (2005). Metode penelitian komunikasi dilengkapi contoh analisis. Bandung: Rosdakarya.

(2007). Metode penelitian komunikasi. Bandung: Remaja Rosdakarya. Rakhmawati, R. (2016). Implementasi kegiatan 
corporate secretary pt. biofarma (persero). PRofesi Humas. Vol. 1, No. 1, Agustus 2016: 40-52

Reza, F. (2016). Strategi promosi penjualan online lazada.co.id. Jurnal Kajian Komunikasi. Vol. 4, No. 1, Juni 2016: 6474

Ruslan, R. (1998). Manajemen public relations dan media komunikasi (konsepsi dan aplikasi). Jakarta: Raja Grafindo Persada.

----------. (2005). Kiat dan strategi kampanye public relations. Jakarta: Raja Grafindo Persada.

Senova, A. (2016). Literasi media sebagai strategi komunikasi tim sukses relawan pemenangan pemilihan. Jurnal Kajian Komunikasi. Vol. 4, No. 2, Desember 2016:
$142-153$

Sugiyono. (2012). Metode penelitian kualitatif, kuantitatif dan $r \& d$. Bandung: Alfabeta.

Venus, A. (2004). Manajemen kampanye: panduan teoritis dan praktis dalam mengefektifkan kampanye komunikasi. Bandung: Simbiosa Rekatama Media.

Wicaksana, R. R. (2015). Kampanye produk minuman kesehatan melalui games interaktif. Jurnal Kajian Komunikasi. Vol. 3, No. 1, Juni 2015: 81-92

Yogi, G. P. dkk (2016). Emergency response plan garuda indonesia. PRofesi Humas. Vol. 1, No. 1, Agustus 2016: 65-77

Yusuf, I. (2008). Filariasis. Diakses dari http:// drismailyusuf.blogspot.co.id/2008/06/ filariasis. html pada Rabu, 14 Oktober 2015 